Article

\title{
Rastafarianism in Bullet Tree Falls, Belize: Exploring the Effects of International Trends
}

\author{
Andrew Gordon
}

Department of Anthropology, University of Houston, Houston, TX 77004, USA; ajgordon@central.uh.edu

Received: 14 December 2019; Accepted: 17 February 2020; Published: 28 February 2020

\begin{abstract}
In 1991, a group of Rastafarians in the village of Bullet Tree Falls, Belize, started out adhering to the principles of piety and protest that characterized the Rastafarians when began in Jamaica in the 1930s. After being Rastafarian for several years, village adherents gravitated to new values and lifestyles, not the protest and piety that kicked off the movement in Jamaica and Belize. The beginnings resembled a revitalization movement, an attempt at making a more satisfying culture. Yet over time, individual Rastafarians in Bullet Tree Falls sought material advantages, and the Rastafarians were flattered by the attention of tourists and others. Changes in the Rastafarians' orientation and practices are examined as a consequence of global trends and local cultural influences. The article examines how international and local trends dissolved a revitalization movement.
\end{abstract}

Keywords: Rastafarians; Belize; international and local cultural trends; revitalization movements and related social movements

\section{Introduction}

This article reports on one aspect of my ethnographic research on the effects of global trends in the village of Bullet Tree Falls in Belize. The village is historically agricultural with approximately 3400 residents, almost all self-identified Mestizos, mostly of Maya and Spanish heritage coming from Guatemala and Mexico in the early part of the twentieth century [1]. Bullet Tree Falls is in the province of Cayo, and the village is about halfway between the northern border with Mexico and the southern border with Guatemala. About 1\% of the village could be identified as Afro-Belizean, what Belizeans call Creole. They were brought as slaves from Jamaica to cut down the forests of Belize in the $18^{\text {th }}$ and $19^{\text {th }}$ century. Some of their descendants became the Rastafarians of the village.

In this research, I examined four global trends that have sought to change this village since 1960, at time when Belizeans were focused on decolonization and independence from England. These trends included a cooperative movement, the development of cultural heritage tourism, becoming Evangelical, and the adoption of Rastafarianism. Unlike most sociological and anthropological contributions, which examine single trends or a single overall orientation [2-7], my book sought to gain a picture of the multiple trends that sum up to make globalization in the village.

One of the global trends visiting the village was the establishment of cooperatives [8]. The cooperative movement had only a minor impact on the village, providing few changes in the way people worked with one another or thought about their work. Villagers were highly individualistic and simply not interested in working together. This was a consistent complaint of all those who tried their hand in cooperative work [1] (pp. 54-83). Eight cooperatives failed after having started several years previously, and the movement devolved into a small group of diehards committed to a cooperative organic farming project. Another trend, cultural heritage tourism, had a record of significant development of tourism in Belize, but not in Bullet Tree Falls. Throughout the country, tourists were eager to learn about Mayan history and culture. They were inspired by monumental Mayan pyramids, residences, and plazas [9] in nearby locales such as Xunantunich 8 
miles away, Caracol a trip of 24 miles and Tikal about 70 minutes away, across the border to Guatemala. In the village, excitement about the possibilities about cultural heritage tourism started out with much fanfare. Villagers thought they would be beneficiaries of tourists' fascination with the greatness of Mayan civilization a thousand years ago. However, tourists rarely came to visit the site connected to the village. Unfortunately for the villagers, the presentation of the site did not include reconstruction of ancient buildings; instead, the natural environment was featured-not of great interest to visitors. Additionally, the project did not go as planned because the founder and developer of the project was viewed with suspicion and seen as too authoritarian by the villagers no longer welcome in the community after a decade [1] (pp. 13-31).

Two other movements were successful in spreading change. They altered life in the village. One movement was the growth of the Protestant Evangelical religion, part of a worldwide change, especially since the conclusion of World War II [10-13]. Evangelical churches became popular in the village, giving residents the opportunity to interact with clerical leadership and participate in a small community with others dedicated to a closer relationship with God and Jesus. The other trend, evident all over the world, was the implantation of Rastafarians [14-21], observed by William Barrett [22] (pp. 25-28) as a revitalization movement in Jamaica, its birthplace. Barrett observes that Rastafarians were using the faith to reorganize their culture and development. It was, in the words of Anthony F.D. Wallace, "a deliberate, organized, conscious effort by members of a society to construct a more satisfying culture" [23] (p. 265).

Of potential importance to the emergence of Rastafarians was the role of charismatic leadership in furthering Rastafarianism, a process described by Max Weber. But charismatic leadership was only part of the story. Apparently attractive and somewhat charismatic, the founding member of the Rastafarians, Leonard Percival Howell, was a minor player in the formation of the Rastafarians. Instead, the emergence of Rastafarians was a collective effort, reaching out to individuals looking for an answer, another way. The Rastafarians began in Jamaica as a small band of about one hundred poor and "dispossessed black underclass in Jamaicans who were often frowned on by the colored class and White elite. They regard their current situation of powerlessness and poverty in Jamaica as a consequence of the evils of colonialism and political chicanery, a system they call Babylon" [24].

A profound changes in Rastafarian practices began to take place in the 1970s in Jamaica. Rastafarians began to lose their way as a revitalization movement. They experienced changes in lifestyle and values. This was a departure from the early Rastafarians who sought to overturn the class structure. During this later time, they were focused on the profession of freedom, the universal regard for personal dignity, the importance of being natural, and most of all, these new Rastafarians lionized the presence of Bob Marley, a reggae singer and a seductive voice for Rastafarian values. The Rastafarians of Jamaica had started out as what will can be described as an "old social movement", focused on political and economic change-an effort to change the class structure in Jamaica. Then, they changed in the 1970s. These changes were emulated in in the village of Bullet Tree Falls and they became even more dramatic. The nature of the changes is the subject of this article.

\section{The Research}

My initial contact with the village occurred in 2008, in the last year of my summer ethnographic field school in the nearby town of San Ignacio. The school was an educational ventured that began in the summer of 2003 and continued until 2008. In the final year of my field school, several students launched a project in Bullet Tree Falls. I followed them there became interested in all the changes in the village. I began my own research there in 2009, during a half-year sabbatical from my teaching post at the University of Houston. Afterwards, I spent summers and the occasional winter break doing research in the village until December 2012.

My contact with the Rastafarians of Bullet Tree Falls started quite early, during the first two weeks of my fieldwork. One night at the village bar-an excellent locale for an anthropologist seeking to make new acquaintances-I met Charlie Waight. He seemed to be about 40 years old. Charlie was 
Creole looking, different than the others in the bar, with darker skin and a fuller face. He was extremely outgoing, spoke English well, unusual in this Spanish-speaking village. He appeared somewhat drunk, a red flag alerting me to possible problems, but he invited me to come to his home and meet his mother. I reflected and asked myself if anyone could be truly dangerous were that person offering to introduce me to his mother? I went home with him, met his mother, and this contact worked out better than I could have imagined. Charlie, I later found, was one of the first to join the Rastafarian movement in 1991 and his father's family were among those who had become the Rastafarians of the village.

\section{The Beginning of the Rastafarian Movement in the Village}

Rastafarianism took hold in the village in 1991 with the arrival of Nelson Young, after he left his life as a successful artist and well-known Rastafarian in Caye Caulker, an island off the coast of Belize. The presence of Rastafarians on Caye Caulker and their involvement with crack cocaine became extremely difficult for Young, especially the stealing and violence he reported. This situation led him to want to settle in the quieter, less fraught environment of Bullet Tree Falls. There, he spread the message that Haile Selassie, who became Emperor of Ethiopia in 1930, was, in fact, the messiah, one who would rescue African populations throughout the world, relieving oppression and enhancing their lives. Young attracted a following of about twenty Creoles in the village, about half of whom were male offspring of his Aunt Adelia's thirteen children. None of Adelia's daughters followed Nelson Young; women were mostly peripheral to the Rastafarian scene in the village.

For three years, Young spread the political and religious goals of Rastafarianism with its fiercely anti-colonialist message. Rastafarians valued the importance of their African heritage and independence from colonial powers. In the style of protest and religious exhilaration, the early Rastafarians constituted what some call an "old social movement" where "class was the central issue in politics and [it was thought that] a single political economic transformation would solve the whole range of political economic ills" [25] (p. 385). What is described as a contrasting position, the "new social movement", recognizes change in values and lifestyle as crucial [26-29]. However, it is not at all clear if the recent Rastafarian expression in the village, as opposed to the change in Jamaica, made for a "new social movement" since participants' sense of belonging to a collective entity is distinguished as a defining feature of a social movement $[29,30]$. Therefore, we may simply define the current Rastafarians of the village as following another cultural trend, not a movement.

At first, Rastafarians accepted a traditional identity of protest and piety conferred by Nelson Young. These new Rastas (the word Rastafarians used to describe themselves) took on a feeling of superiority, having been delivered into a superior world, far more so than their Evangelical co-villagers recently converted from Catholicism to Protestant Evangelism. These Evangelicals followed a global trend of conversion especially prominent in Latin America. While the Evangelicals were preparing themselves for Judgment Day and the Second Coming, the Rastas considered themselves in a better place since the Rastafarian messiah, Ras Tafari, had already arrived.

Ras Tafari was Haile Selassie's name before he was inaugurated as Emperor of Ethiopia. Followers of Haile Selassie from the 1930s onwards called themselves Rastafarians in reference to Selassie's birth name: Ras, meaning "head," and Tafari, meaning "the one who is feared." Also, village Rastas took pride in their ethnic identity as descendants of Africa. They were attuned to their origins, giving the name "Roots "to their all-Rasta village soccer team, an obvious nod to Alex Hailey's account of African beginnings in the Americas, in his famous book titled "Roots" [31].

As a Rastafarian missionary, Young spent considerable time teaching his artistic skills to the Creole population. Before coming to Bullet Tree Falls, Nelson Young had been a well-known artist in Caye Caulker [32]. After his arrival in the village, as a young man of 34 , his fame become widely recognized in the village as it had been throughout the country and this raised his local stature. Young was a polymath in the arts. He taught his followers about sculpting, painting, crafting furniture and leather goods, and making macramé. Today, the Rastafarians who spent time with him all recall their having developed an appreciation for their possibilities as artists. Many were dedicated to using the materials 
from nature (seeds, bones, woods, clays, etcetera) to make furniture, sculptures, and jewelry; all items which were sold to tourists on the streets of nearby San Ignacio. Some followers of Young became well known in the area and even developed international reputations like painter Jorge Landero [33]. Creole Rastafarians began to understand that there were ways of making a living other than being a small farmer, the tradition of Mestizo villagers, a practice the Creoles denigrated, having once been owners, not workers, on this land.

Young also encouraged his following to adhere the basics of being Rastafarian: studying and discussing the Bible, knowing the importance of Haile Selassie, growing dreadlocks, smoking ganja, and taking nourishment from ground foods, called Ital in the Rastafarian argot. Young cooked stews of squash, potatoes, onions, and peppers for his followers. In the following words Young reflected on his experiences in the village:

The lifestyle that I was bringing to them was something new to them. I was bringing to them what you call extreme kindness, and love and respect. Not only in the word, but in the works and the action. And I was bringing to them humbleness, humbleness and lowliness. I was bringing to them high things.

\section{Expressions of Protest in Jamaica}

Nelson Young's role in the village resembled the activity of Leonard Percival Howell in Jamaica in the early 1930s. In the following decade in the 1940s, the Rastafarians set up a commune called the Pinnacle, located in the village of St. Catherine, seventeen miles from Jamaica's capital city of Kingston. The norms and practices of the Rastafarians became part of the Rasta way. Many of their practices derived from religious edicts from the Bible. They were to eat Ital foods (natural foods, no meat, and only those fish small enough as not to be predatory), wear their hair in dreadlocks, use ganja (marijuana) extensively, commit to Bible study, reject the materialist European colonialist world, and regard Africa as the source of rejuvenation for the sons and daughters of the African diaspora. Rastafarians eschewed the materialism associated themselves with the Jamaican state and a valued contemplative existence. Also, the Rastafarian way valued African origins, drawing on an Afro-religious sect called Kumina and its ceremonies of drumming and chanting, called Nyabinghi, [34,35] (p. 21) [36,37]. Leonard Barrett, a leading scholar on Rastafarian culture, has recognized six features as specific to the Rastafarian way:

1. Haile Selassie is the living god.

2. The black man is the reincarnation of ancient Israel, who at the hand of the white man has been in exile.

3. The white man is inferior to the black man.

4. The Jamaican situation is a hopeless hell. Ethiopia is heaven.

5. The invincible emperor of Ethiopia is now arranging for expatriated persons of African origin to return to Ethiopia.

6. In the near future, the black man shall rule the world [22] (p. 104).

The Rastafarians presented a counterpoint to the image of loyal Jamaican colonial subjects of England. With the Rastafarians being unshaven and with dreadlocks, other Jamaicans perceived them as dangerous outlaws. The colonial administration in Jamaica gave them no peace, persistently prosecuting Rastafarians under laws against marijuana use and cultivation. Finally, forceful government action against the Pinnacle in 1954 caused the Rastafarians of the commune to disperse throughout Jamaica. After their dispersion, the movement eventually grew in numbers, ranging from 15,000 thousand to 20,000 and by some estimates, their numbers reached 70,000 by the end of the 1950s [38] (p. 49).

The Rastafarians were an expression of a continuing pattern of religious and political protest in Jamaica. Political movements were led by pastors such as Sam Sharpe, also known as Daddy Sharpe, who led slaves in an uprising in Montego Bay in 1831 that would later be called the Baptist War Slave Rebellion. Jamaicans throughout the country supported this uprising in which two hundred black rebel 
Jamaicans fought and died in protest against colonial domination of the English; while only 14 whites were killed. Later, in 1865, Pastor Paul Bogle led a march that protested colonialism. The body count was not so lopsided since both sides of the confrontation were killed. Afterwards, Bogle was captured and publicly hanged. This action by the colonial administration and Bogle's activity continues to be regarded as memorable and heroic [39] (pp. 38-67).

The idea of Haile Selassie, which bore deeply in the consciousness of his followers, also took on religious significance. Salassie's position as the messiah was affirmed on personal grounds affirming his position as inheritor of a religious tradition. According to the accounts, Selassie's ancestry was distinguished in that he was a descendant of the Biblical Queen of Sheba and King Solomon [40,41]. Marcus Garvey reportedly added religious importance to Haile Selassie. Garvey was allegedly invoked Psalm 68, which prophesied the appearance of Selassie. The psalm referred to "Princes [that] shall come out of Egypt". He is said to have encouraged the "Negro race" to back Haile Selassie. Garvey's words were important. He was well respected as an activist and businessman, with important accomplishments, worldwide, as a result of his founding the United Negro Improvement Association (UNIA), a confederation of black-owned businesses that included grocery stores, restaurants, cleaners, publishers, and a shipping line with three commercial ships intended to transport the African descendants back to their homeland [42-44].

\section{Expressions of Protest in Belize}

The ascent of Rastafarianism in the village in the early 1990s was, as well, founded on an inclination for protest. Written records in Belize date back to the riot of 1894, when Creoles revolted against their British employers [45] (p. 43). Again in 1917, Creole laborers in Belize City rioted, agitating for better working conditions and pay. There was also the Ex-Servicemen's Riot in 1919, again in Belize City, after Creole soldiers returned from the Middle Eastern theater of war. Creoles expressed rage against continuing racism overseas and the fact that English and European soldiers treated the Creoles as despised servants [46] (p. 23), [47]. Enraged, the ex-soldiers broke into the houses of British whites and "near-whites" in Belize City, yelling, "These are brutes! We do not want them here!" "This is our country, and we want to get the white man out!" and "We are going to kill the white sons of bitches tonight ... . This is a black man's night!" [47] (pp. 56-57). The sense of discontent among Creoles increased with Marcus Garvey's visit to Belize in 1921, when he exhorted the Creoles to act in their own interests [48].

In 1970s, the Creole population of the village had become oppressed, not by the English Colonialists but, instead by Mestizos who wanted to revenge against colonials' servants who happened to be the Creoles of the village. The country was moving toward independence, and the spoils of that independence went to the Mestizos.

Prior to the move to independence, the Creoles of Bullet Tree Falls were beneficiaries of colonial power. By virtue of a nineteenth-century land grant from the British crown, John Waight, a Scotsman, was granted land from the British government. Waight and his descendants had children with Creoles and the children had children with Creoles. Eventually, the Waights were identified as Creoles and they became the ruling class of the village. As a result of the land grant they owned territory from the village all the way to the nearby town of San Ignacio, three and a half miles away.

The decline of the family is said to have begun when John Waight, the family's head, lost a major portion of his wealth in a bad bet during a drunken poker game. This debt left the Waight family with only two thousand acres in and around Bullet Tree Falls. They carried on nevertheless, renting out the land to the villagers. However, those two thousand acres were lost as well, when in the late 1960s, the soon to be independent government of Belize began to expropriate land that had been granted to British subjects. Then, the Waight family became landless with their children were no longer inheritors of an estate. The children had no experience in agriculture, and they could claim little other than a historic affiliation with colonial culture and privilege. After losing their position and wealth, the family 
suffered from a backlog of resentment from those they subjugated. It was a case where the colonial ruling class eventually became the oppressed.

Throughout Belize, there was a discourse that the beneficiaries of independence, the Mestizo population, was the enemy of the Creole. Journalist, author, newspaper and media tycoon, Creole Evan X. Hyde was the militant voice of Creole determination in Belize in the last third of the twentieth century. He articulated the grievances of the Creole position and extensively and denigrated Belize's leader George Price, the one regarded as "Father of the Country", calling him "Mayan racist" [49] (p. 230). Hyde argued that Price's sentiments were clearly demonstrated by the BZ \$20 million project to build a new Belizean capital in Belmopan after the hurricane in 1961. Belmopan was in the heart of Maya country, and its development was viewed as a preferred alternative to reconstructing the South Side of Belize City, home to the Creoles. Hyde reviled the design of government buildings, which were in the style of Mayan ruins, with wide expanses of steps cascading into public plazas. From Hyde's viewpoint, the design was a valuing of Mestizo heritage, privileging the Mayan greatness of their ancestors, a thousand years earlier. Resentments between Creoles and Mestizos continued throughout the twentieth century and beyond [50-52], each assuming the other as an interloper in Belize, each claiming to be more Belizean, each with stereotypical ideas about the other, feeling their own position to be truly Belizean and that they should be the ones to benefit from decolonization.

The Mestizos' negative attitudes toward Creoles intensified in Bullet Tree Falls. The Waight family was openly reviled by the farmers to whom they had rented land. Administration of the land dictated that crops could be grown for only a year at a time. Therefore, farmers could not plant any trees for edible fruit or for construction. If a renter broke the rules, the punishment was a swift smack from the flat side of the Waight administrator's machete.

Also, from the 1940s through to the 1960s, a cadre of Garifuna elementary school teachers arrived in the village. Garifuna were initially a community of escaped slaves in the Caribbean coming to Central America in the late eighteenth century. Over time in Belize, the Garifuna established themselves as loyal colonial servants to the English and they and became village teachers. From the villager's point of view, the Garifuna were indistinguishable from the Creoles. Black was black, and Garifuna were black. They were lumped in with the Creoles and the offenses of the Garifuna were due to being of African heritage, just like Creoles.

The Garifuna's behavior created enmity. They criticized the Mayan oral tradition dwelling on magical dwarves (duendes) and made fun of the Mayan belief that frogs came from the sky when it rained. Mestizo villagers recalled that the teachers did not hesitate to lash out with a stick with any students who spoke what the Garifuna called the "inferior languages", Maya and Spanish.

Even in the 21st century, villagers were similarly ready to express their contempt toward Creoles, especially those who were "negro, negro" (black, very black). They found the Creoles audacious-too bold, loud, and overly confident. Their Christian pastors echoed these sentiments, claiming that Creoles were too "licentious," unsuitable and unwilling to become "obedient servants of the Lord." Creoles recall open hostility. Charlie remembered his youth in the 1980s when villagers, including his Mestizo uncles, called him "Blackbird". His fellow Mestizo students called him Negrito in school, "the little black one."

\section{Changing Rastafarians}

By 1994, however, life had changed for the Rastafarians of the village. They lost their guru and guide that year. Their source of inspiration and new identity, Nelson Young, picked up and went back to Caye Caulker. In discussion with Young in 2012, 18 years after his departure, he said he thought it was just time to move on; his work had been done. He had implanted an appreciation for the Rastafarian way. When Young departed, village Rastafarians no longer had their cultural compass orienting and affirming an enhanced identity. Others took the place of Nelson Young; they conferred importance on the Rastafarians. At first, admiration came from the archeology students who valued the Rastafarians. These students arrived in 1994 to begin excavation of the Mayan site, El Pilar, what 
was to be the tourist attraction near Bullet Tree Falls. Tourists had their own ideas of what Rastafarians should be, how they should act. For students, as for tourists who were to follow, Rastafarians were associated with music and romance and what came to be appealing symbols, such as dreadlocks, patterns of speech, colors, and certain phrases associated with the Rastafarian way, such as praise to God ("Jah" in the speech of Rastafarians) and nature, eschewing materialism, and being natural. Notions of Rastafarians were wholly romanticized.

El Pilar. eight miles from the village of Bullet Tree Falls, was a Mayan site of architectural splendor, the center of a city-state reaching its peak of development about a millennium ago. One hundred and twenty-eight acres of monumental structures could have been presented. The village was to function as the gateway to El Pilar. A local community-based organization in Bullet Tree Falls called Amigos de El Pilar stoked considerable excitement about a future with this archeological attraction. Eighty-nine villagers and local friends joined the Amigos group, which was to actively guide and advise the development of the village on its future with cultural heritage tourism.

Bullet Tree Falls was to follow a course of development in line with the town of San Ignacio, the hub of tourism for this area of the world, the center for a hospitality industry featuring Mayan pyramids, royal residences, ball courts, and plazas. In the town of San Ignacio, touring companies sprung up and with their minibuses the companies transported backpacking tourists from North America and Europe to the many nearby Mayan archeological sites reconstructed by archeologists [53-55]. Bullet Tree Falls was slated to participate in the tourism boom. Rastas were ready for this global trend; they adapted to tourists and the Rastas also functioned as a welcoming committee for the tourists.

\section{Rastafarians and the Mayan}

It was not only the Mayan presence that intrigued the tourists. Rastafarians also piqued their interest. Anne Sutherland, an anthropologist studying Belize, wrote of the Rasta scene in Caye Caulker in the 1980s, "White tourists from Europe and the United States seem to have an endless fascination with the exotic dreadlocked Rastas and reggae music" [56] (p. 114). Eventually, the attraction of Rastafarians was all over Belize. Dutch anthropologist Van Wick wrote of dreadlocked men on an island offshore of Belize who were ready to develop romances with visiting women [57]. In an article on a community near Placencia, on Belize's Gulf waters, American-based researchers Key and Pillai reported young dreadlocked men ready to squire female tourists [58].

With Nelson Young's departure and with the beginning of Anabel Ford's excavation, village Rastafarians caught onto a wholly different way of presenting themselves. The presentation was largely modeled by Jamaican Bob Marley who inspired a major change in what it meant to be Rastafarian. The Rastafarian way was no longer Afrocentric. Marley said, "God never made no difference between black, white, blue, pink, or green. People is people, yuh know. That is the message we try to spread" [24] (p. 184). Without doubt, Bob Marley, a singer and effectively a troubadour for the Rastafarians, had a major role. The lyrics of his songs conveyed Rastafarian beliefs of the 1970s, specifically the importance of individual dignity and the value of being natural and sentient. The music captured a worldwide audience. Bob Marley was featured in the Rolling Stone magazine, appearing on three magazine covers for the American audience and on one cover for the French, Spanish, and Portuguese editions. His music was wildly popular all over the planet, distinguished by a use of several guitar lines, syncopated drumming accompaniment, and call-and-response lyrics that recounted Rastafarian themes. As the fame of reggae spread throughout the world [59-62], many came to learn of the Rastafarians. Being Rastafarian was a new idiom of communication. Both tourist and host ascribed to common values: the dignity of all people, appreciation of indigenous ways, being embedded in a community of soulmates, and continual marijuana use.

The worldwide diffusion of the Rastafarian ethos was carefully planned by other Jamaicans. The presentation of Marley was promoted and guided by the Rastafarian savant Mortimer Planno, whose efforts resulted in Jamaica being the epicenter for Marley's popularity in the 1970s. Planno saw 
Marley as a man who could be groomed to serve as an instrument of Rastafarianism and spread the message in Marley's reggae music [63-65]. Planno was clear about the role he played.

Now, there was a Bob Marley who was a rude boy which is a different Bob Marley from the Bob Marley that I ... know. So we're going to mould Bob Marley the rude boy into Bob Marley the Rasta messenjah who carry Jah message [the message of the Rastafarian God, Jah] through the whole world [66] (p. 157).

Chris Blackwell, Marley's manager, was almost as important as Planno in advancing Marley. Blackwell was a wise promoter of reggae music, refining the sound so it included American Black musicians with a soundtrack that resembled American Black music, not the rougher texture of reggae. As a result of his efforts this music was popular everywhere [59-61].

Reggae music became a symbol of the new cultural face of Jamaica, an advertisement for a peaceful, loving countercultural presence that would attract tourists. In 1991, the Jamaican Tourist Board made Marley the face of Jamaican tourism with an advertisement featuring him singing his well-known song, "One Love". It all conveyed a sensuous image that was part of this new Rasta ethic. Female visitors to Jamaica heard, "If you come to Jamaica and never sleep with a Rastaman, the true, natural man of Jamaica, you never really experience Jamaica and yourself" [67] (p. 427).

In Jamaica, Rastafarianism and reggae entered the political mainstream, viewed as acceptable by Prime Minister Michael Manley on the left and by his political opponent, Edward Seaga, on the right. Before that time, the Jamaican government had banned controversial reggae songs. But afterwards, in the 1970s, reggae and Rastafarian practice became entrenched in Jamaican popular culture [68]. Reggae and Marley were positioned as important features of Jamaica, soon to go international. John Homiak, a Rastafarian scholar working at the Smithsonian, notes that the growth of this group was "globalized, diffuse, and de-territorialized," powered by the "global flows created by the communication and media technology of the late 20th century" [15] (p. 88). Despite the popularity of the Rastafarians and the reality that they were no longer on the margins of society it should be mentioned that there was a continuing of a pattern of protest and Afrocentric expressions that characterized the era Leonard Percival Howell. The scholarship of Charles Price [69], Leonard Barrett [22], and Obika Gray [70] reports on those who were Rastafarian in the old style, represented by those who remained at a remove from the alternative values and lifestyles symbolized by Bob Marley.

\section{Rastafarians in the Belizean Village: Romance and Money}

The actions of archeology students affirmed the importance of this new way of being Rastafarian. Charlie learned that growing his dreadlocks even longer improved his success with women. Over eight field seasons, he reports he had eight girlfriends from California, Canada, England, Germany, Mexico, and elsewhere. As well, there was influx of female backpacking tourists eager to be in touch with the local Rastafarians. Women coming to visit the Mayan sites could be quite deliberate in their search for Rastas. The Rastas provided a secondary and almost as compelling a reason to meander around Belize. The owner of a tourism business in San Ignacio told me that he had found a journal that a young traveler had left in his microbus. A page in the journal recounted a list of travel goals: "go to Tikal" (an archeological site in Guatemala), "go to the beach," and, the one that caught his eye, "experience a Rasta man." In San Ignacio, one frequently saw young women from their late teens well into their twenties with "I love Rasta" emblazoned on their shirts.

The Rastas' search for tourist companions fitted well with Rasta economic problems. Rastas were without any steady métier or line of work, like the traditional vocation of their co-villagers who were farmers or working in retail in San Ignacio. Any money for their artwork was seasonal and unpredictable. When the tourists arrived, they sought out a companion or friend, often one with a romantic interest. The Rastas found generous tourists to be a splendid buffer against potential poverty.

The Rastafarians became involved in romance tourism. The term "romance tourism" was introduced by anthropological researchers in Jamaica who studied the attractions and successes of 
Rastafarians in their relationships with female tourists [67]. Village Rastafarians were the beneficiaries of this practice. In 2006, Jeannette Belliveau published an entertaining and seemingly credible encyclopedia of women who were traveling to have sex. The book "Romance on the Road: Travelling Women Who Love Foreign Men" used a variety of sources and sampled testimony from some of the approximately 600,000 women a year who crossed geographical and cultural boundaries to find romantic liaisons [71]. On reading the book, it is apparent that romance tourism is a mix of motives. Companionship, sex and romance are apparent. However, there is a constant: the continuing objective of male hosts to gain the material benefits, gifts, means and entertainment from the more affluent tourists. However, I must add that certainly there have been some very genuine loving relationships that taking place between Rastafarian hosts and tourists. But the reality is that there was sex or romance tourism [72,73], and village Rastafarians were involved.

Starting in the late 1990s, village Rastas were often gigolos for female tourists. Visiting tourists rewarded personal attention from Rastas and were known to provide "gadgets" as gifts such as cell phones, iPods, and iPads. At times, a Rasta would receive a big payoff from a visitor: a paid trip to the United States, Canada, or Europe. Garan Lyles and Kimberlee Schluter, students in my ethnographic field school in San Ignacio, reported that the men hanging around San Ignacio, many of them village Rastas, typically started out as companions, confidants, and guides to female tourists. Encounters usually began in a bar or restaurant and ended in the tourist's hotel room. The following morning, these young men pursuing tourists would gather over breakfast. They compared notes on how well things were going, mostly reporting on material benefits from the women they had met and speculating as to how long a relationship might endure. When a female companion left town, her host would be on the lookout for a replacement. Garan described these men as "lost boys" without a clear future, just getting by for the present. Temporary liaisons were frequent enough to keep thirty to forty men in San Ignacio occupied for several nights a week.

In the village, I found one very successful self-identified Rasta, Roberto, then about 40, who could look back at a history of always squiring female tourists. Around the time of my fieldwork, he had allied himself with a young lady and traveled frequently to her home in England. Because he looked Rasta, he reported, "They treat me like a rock star." The story of his getting together with this English girlfriend is typical of narratives in the village:

I was fricking drunk one night and we started to talk, and I tell some jokes that we did some dancing and she was checking me out. It was madness you know. And she invited to the jungle lodge where she was student and I end up staying there for the night and then the next day and then three days pass. And she decided to go to Mexico, and she asked me to go. Then she would go home, and I would go home. We were to spend a week in Mexico, but we spent a month. Then she cried and went home, and she was back in two weeks to Belize.

Roberto had financial backing from previous girlfriends, including an American girlfriend and support for a business conducting horseback tours around the village. With another girlfriend, he opened a restaurant in nearby San Ignacio. Roberto's brother, also a Rastafarian and a Waight, had started a small resort in the village with the help of his American wife. This resort had a Rastafarian air, with its stated purpose being to serve the best organic foods and host retreats for those who practiced yoga.

\section{Doing Your Own Thing, Being Rastafarian in Belize}

The Rastafarian presence in the village strayed far from the contours mapped out by Leonard Percival Howell. And village Rastas only partially cleaved to the newer edition of being Rasta inspired largely by Bob Marley. In Bullet Tree Falls, being Rastafarian became an open category to which one might improvise and add flourishes as they wished. Rastas in the village incorporated local concerns and themes of Mayan culture in their Rastafarian practices. This meant being "back-a-bush", as they say in Belize, to describe the rustic ways of a people accustomed to life in the tropical forest. Belizeans in 
rural areas prided themselves on their capacity to clear the rainforest and ready the land for their milpa, the single-family farm typifying Mestizo rural life. Consistent with the "back-a-bush" ethos, Charlie and his cousin Norberto, another Rasta, independently, built shacks, altogether rustic, supposedly for tourist rental so travelers could get off the beaten path. But they had no renters. The shacks were basic: no toilets, no running water, no electricity. This was not a money-making scheme-far from it. I asked Charlie and Norberto just how many tourists they had had in the last four years. "None," he said, seemingly unperturbed. These ventures shored up their personal identity; that was their apparent purpose.

Charlie's shack underscored his Rastafarian affiliation, and he had put up hand-painted signs on the shack's outer wall featuring short passages from the Bible along with a sketch of the Star of David, and an image of the Lion of Judah, another representation of Ras Tafari. Norberto, too, had made a pitch for the tourist traffic with a hand-lettered list of services painted on a sign outside his shack. The list included canoeing, biking, birding, and nature walks. His Rasta side came out at night in clubs; when there was a microphone available, he sang reggae songs. Manolo, who was not a self-identified Rastafarian but hung out with them, followed similar themes of ganja use, tourism promotion, and an emphasis on Mayan heritage. He had built a Maya-style cave in his backyard with bas-reliefs of Mayan masks. Good for tourists, he thought, but few came. All his excellent sculptural work was a surprise to me, given that he was high on ganja almost all the time. A similar pattern of work was followed by Crispin, another fellow traveler to the Rastas. He developed a nature preserve that highlighted the different types of plants and herbs grown in the region, but almost no one came there, either.

Rastafarians learned how to market themselves as artisans, selling their wares to tourists on the streets of San Ignacio. They proudly spoke of "di jungle" in a sort of Rasta patois, hinting to visitors and prospective buyers that they had intimate knowledge of the rainforest. They would point out all the materials from nature used in their work. These Rastas also embraced and showed off their attachment to Mayan food. For visitors, they served up tamales, what they called bollos, and a pibil, a whole pig, cooked underground with spices, and, of course, ganja. In turn, visitors rewarded their hosts with rum and monetary contributions. The Rasta-Maya mix was in their music, too. I came across a CD made in the mid-1990s, its cover showing Charlie on the guitar along with Jairo, a Rasta jewelry artisan, on the conga drums. Their lyrics, sung in a Rasta patois, kept a reggae beat. The theme was a condemnation of colonialism, and echoing Rasta protests about slavery and the oppression of black peoples - sentiments transposed on Spanish colonizers and their relations with the Maya:

- Columbus, Columbus, Columbus

- Fir mi di ya long before Columbus

- (Translation: Fire was here long before Columbus)

- Mayas mi di ay long before Columbus

- (Translation: Mayas were here long before Columbus)

- Columbus, Columbus, Columbus

- Come bust us

The point of the lyrics was that the Maya had their culture, their civilization, as indicated by fire. All the Spanish did was subjugate and overlook Mayan accomplishments. Behind the words was the exhortation of Bob Marley, "Stand up for your rights," the title of one of his most popular songs.

For others, being Rastafarian was an open category having nothing to do with Belizean rural back-a-bush themes. Being Rastafarian was a deployment of the cultural allure and significance of being Rastafarians. In the course of my research, I met three Rastafarians, all nationally known, who had come to Bullet Tree Falls from Belize City, the metropolitan hub of Belize, one hundred miles away. Each did their own thing. Each had no identification with any back-a-bush experiences. They were urban, without any Mayan influences, having lived among urban dwellers in the urban environment of Belize City. Each had their own version of being Rastafarian and used their Rastafarian identity as a resource to appeal to others. 
One of the three was Danny, in his late fifties, who had first come to Bullet Tree Falls in the mid-1990s. He had been an on-and-off presence there until he built a house around the year 2000. Another was Joseph, aged sixty-seven, from Jamaica, who had come to Belize in 1998 and had been an intermittent presence in the village since then. The third that I met was Pulu, in 2012, also in his late fifties. He bought a plot in Bullet Tree Falls, as he was eager to have land in all six districts of Belize, though he never took up steady residence in the village.

\subsection{Danny}

Danny's version of being Rastafarian traces changing identities throughout his life. When young he acquired the nickname "Tourist". Others saw him always hanging around tourists. Accompanied by visiting women, he attended the dance clubs of Belize City, always splendidly dressed-flashy, in fact-and sporting a beret. He became known as Ras Beret. He took visitors on tours, going first to Belize City, then to Caye Caulker, then to Xunantunich, eight miles from Bullet Tree Falls, and then to Tikal. After moving to Bullet Tree Falls in his forties, however, he changed, no longer being a candidate for the tourist hustle of the younger Rasta scene. From then on, he more closely resembled an earlier edition of Rastafarianism, being quite pious and contemplative, more in line with the old faith demonstrated by William Percival Howell's social movement. He lived alone or with his son, removed from other villagers. He, like Nelson Young, sought to settle in Bullet Tree Falls. Danny wanted a quiet life, to be around nature, with the river running through the village, close to the nearby mountains, and with the opportunity to have a garden where he could grow ground food for his "ital" diet. The course of his life had spanned the two traditions, first in the lifestyle and universalistic expression of Bob Marley and later following an older model of Rastafarianism: thoughtful, religious, insulated from larger society. He had adapted to his age and circumstances, reinterpreting Rastafarianism according to his personal identity.

\subsection{Joseph}

Throughout his life, Joseph had been closer to the older version of being Rastafarian. He had a long history as a Rasta, first inspired at age twenty-one by Haile Selassie's visit to his native Jamaica in 1966. At that moment, he was sold on the Rasta way. When he came to Belize in 1998 from Jamaica, he drifted all over, substantially isolated from the larger society. He explained that this sort of traveling was the "Rasta way". He was not to be tied down, going from Belize City to Bullet Tree Falls, and sometimes to Sand Hills, all settlements for Rastafarians.

Joseph was a untiring spokesman for the divinity of Haile Selassie and the importance of solving the problems of African descendants. For eight years, he lived and worked in Liberty Hall, the building constructed for Garvey's UNIA movement. Joseph was the caretaker, but he did not describe himself as simply a caretaker or guard. Instead, he said he was the self-described "cultural master of the UNIA," giving tours of Liberty Hall, speaking about the UNIA initiative and about Isaac Morter, the benefactor for the construction of the UNIA hall. In the village, he spoke of the need to "feed the children," as they were "the kingdom of Heaven," echoing a sentiment very much part of the Rastafarian ethos. His speech was continually laced with references both to Jah and to the African origins of Rastafarianism. Eschewing material possessions, he ate little, kept to himself, and managed to be continuously high on marijuana.

However, he did not resist the gambit of attracting international tourists, very much part of the way of life in the village Rastafarians. Joseph was a reggae singer and always selling his homemade CDs to tourists. On the CD cover, one could see a picture of him sporting a long beard and dreads, the longest in Belize, he claimed. Tourists found him to be the genuine article. His laid-back attitude and extensive hair growth were celebrated in a YouTube clip that has garnered 1.6 million views [74]. He was a clever mix of Rasta presentations, fitting in with what was appropriate for the moment. 


\subsection{Pulu}

A third type of self-presentation is found in Pulu Lightburne. His buying land in the village and in every other district of Belize was consistent with his self-presentation as a national personality. Pulu in no way conformed to the old-school version of the faith, which required sticking to ital foods, avoiding alcohol, being religious, and being marginal to the rest of society. In all facets of his personality, he was quite the opposite of what a Rastafarian should do. On more than one occasion, we shared beef and beer, yet he appeared to have projected Rastafarian symbolism throughout his adult life, very much as a means of self-promotion, to raise his popularity. After his college years in the United States, Pulu reappeared in 1977 on the Belize national basketball scene. He became a high-profile player and manager, known to bring fans to pitched excitement when he headed his own team, called Jah Jam. The Rasta image was obvious, especially in appropriating the word Jah. As a manager, Pulu had his team members came out for warmup practice wearing Rasta colors, with the music of Bob Marley blaring from the public-address system. This was a Rastafarian show. Even his team's defensive strategy on the court, effectively a full-court press, took on Rasta references when Pulu named the move "the lion," referring to Haile Selassie, who was described as the Lion of Judah, a biblical reference.

Pulu also became a public personality beyond basketball. He appeared in local publications and voiced his opinions on the radio concerning the need for decriminalization of marijuana. He was so widely appreciated that George Price, the political leader and prime minister of Belize, selected him to be the director of national youth sports from 1980 to 1982. In recent years, Pulu has become known for his foundation and his work addressing the hardscrabble neighborhood of Belize City's South Side, where gangs flourish. Lately, he has turned his attention to Belize's small film industry, playing roles in science fiction centered on themes of the Maya and their contact with aliens. He had no social association with groups of Rastafarians in Belize as existed within the Pinnacle. His ties were symbolic. His being Rastafarian was strictly a modern and commercial creation, truly inventive, if not ingenious, in the way he traded on his Rasta association.

The experiences of these three who came to Bullet Tree Falls show how being Rastafarian was given to considerable improvisation. Rastafarians were able to appropriate signs and symbols of being for personal gain. These three, along with the Rastafarians born in the village, added to the legitimacy and importance of Rastafarians as a part of the fabric of the local culture. The overall effect lent an image of openness and flexibility in dealing with the outside world. These Rastafarians were a connection to visiting tourists, providing contact and friendship with those North Americans and Europeans who sought out locals who subscribed to values of openness, an appreciation for alternative and countercultural values, and with a readiness to share marijuana.

Rastafarians in the village grew adept at fashioning social relationships, much as Charlie had done when I first met him in the bar. With all this friendliness, the village became known as a welcoming place, one described by an American resident as having a "hippie vibe." By 2000, some one hundred North Americans and a small number of Europeans had bought lots on which to build retirement homes or second homes for vacation use.

\section{Conclusions}

In the village, Rastafarians became associated with a countercultural persona: being nonmaterialistic and natural, guided by reggae music, and valuing a change in mind brought on by the euphoric qualities of marijuana. Gone was the menacing anti-establishment image made more obvious by straggly beards and dreadlocks. The dreadlocks remain but are no longer a threating posture of Afrocentric expression. Instead, the presentation is humanist and Rastafarians uphold human dignity and standing up for everyone's rights. There are aspects of global influence, emanating from Jamaica-Bob Marley, tourism and the sexual revolution. Also there are commonalities shared by Jamaica and Belize. Both nations experienced a cessation of colonial domination; both experienced the acceptability of relations between ethnic groups; both developed an openness and acceptance to those of a different social classes and with a different points of view. But we definite differences. In the 
village there is the influence of local cultural influence and national themes, quite apart from distinctly Jamaican influences: the Mayan rustic past and the liberty to express one's Rastafarian affiliation just as one would want. Thus we may recognize a mix of cultural forms, sometimes described as hybridity [75] that or that which is "glocal," a mélange of the global and local [76]. But it would be an overstatement to assert the transformation of Rastafarian themes in the village was an outcome of globalization. Far more examples would be needed outside the setting of Belize to affirm that the Belizean case is an example of globalization.

Without doubt, the village breathed new life into Rastafarian practice. Village Rastafarians were at geographical remove from Jamaica; Belizean Rastafarians were without the Jamaican national ethos supporting Rastafarian practices and beliefs; and villagers did not display a collective sensibility related to the coherence of purpose characteristic of social movements and revitalization movements. Instead, Rastafarian villagers went off in their own directions, appearing to use a Rastafarian affiliation as personal resource. They no longer subscribed to a Rastafarian affiliation that compelled them to change the world around them. Instead, a combination of global trends and local influences enabled the villagers to create their own version of being Rastafarian.

Funding: This research received no external funding.

Acknowledgments: The author would like to express appreciation to the University of Houston for the opportunity to devote my sabbatical to work in Belize and to the Small Grants Program of the University for research support.

Conflicts of Interest: The authors declare no conflict of interest.

\section{References}

1. Gordon, A.J. Agents of Change in Bullet Tree Falls: How a Village in Belize Responded to Influences of Globalization; Cengage Learning: Boston, MA, USA, 2017.

2. Canclini, N.G. Consumers and Citizens: Globalization and Multicultural Conflicts; University of Minnesota Press: Minneapolis, MN, USA, 1995.

3. Lash, S.; Jonathan, F.J. Modernity and Identity; Blackwell: Oxford, UK, 1992.

4. Inda, J.X.; Rosaldo, R. The Anthropology of Globalization: A Reader; Wiley-Blackwell: Hoboken, NJ, USA, 2008.

5. Lewellen, T.C. The Anthropology of Globalization: Cultural Anthropology Enters the 21st Century; ABC-CLIO: Santa Barbara, CA, USA, 2002.

6. Martell, L. The Sociology of Globalization; John Wiley \& Sons: Hoboken, NJ, USA, 2016.

7. Robertson, R. Globalization: Social Theory and Global Culture; Sage: Thousand Oaks, CA, USA, 1992; Volume 16.

8. Williams, R.C. The Cooperative Movement: Globalization from Below; Routledge: Abingdon, UK, 2016.

9. Dallen, T.J. Cultural Heritage and Tourism: An Introduction; Channel View Publications: Bristol, UK, 2011; Volume 4.

10. Stoll, D. Is Latin America Turning Protestant: The Politics of Evangelical Growth; University of California Press: Berkeley, CA, USA, 1990.

11. Berryman, P. The coming of age of evangelical Protestantism. NACLA Rep. Am. 1994, 27, 6-10. [CrossRef]

12. Reese, S.J.; Thomas, J. The Hidden Exodus: Catholics Becoming Protestants; National Catholic Reporter: Kansas City, MO, USA, 2011; Available online: https://www.ncronline.org/news/parish/hidden-exodus-catholicsbecoming-protestants (accessed on 14 December 2019).

13. Mendoza, G.J. Why do Catholics become Evangelicals? In Homiletic and Pastoral Review; Ignatius Press: San Francisco, CA, USA, 2007; pp. 8-17.

14. Baulch, E. Making Scenes: Reggae, Punk, and Death Metal in 1990s Bali; Duke University Press: Durham, NC, USA, 2007.

15. Homiak, J.P. Movements of Jah people: From soundscapes to media scapes. In Religion, Diaspora and Cultural Identity: A Reader in the Anglophone Caribbean; Pulis, J.W., Ed.; Gordon and Breach: Amsterdam, The Netherlands, 1999; pp. 87-123.

16. Loadenthal, M. Jah people: The cultural hybridity of white Rastafarian glocalism. J. Cult. Politics Innov. 2013, $1,1-21$. 
17. Poole, N. White Rastafarians. Available online: http://www.africasource.com/rasta/sesotris-the-greategyptial-hercules/white-rastafarians-by-nick.poole (accessed on 19 December 2016).

18. Savishinsky, N.J. Transnational popular culture and the global spread of the Jamaican Rastafarian movement. New West Indian Guide 1994, 68, 259-281. [CrossRef]

19. Wackengut, A. Rastarfari in Germany: Jamaican roots and global-local influence. Stud. Anthropol. 2013, 3, 60-83.

20. Yawney, C. Rasta mek a trod: Symbolic ambiguity in a globalising religion. In Arise Ye Mighty People! Gender, Class and Race in Popular Struggle; Turner, T.E., Ferguson, B., Eds.; Africa World Press: Trenton, NJ, USA, 1994; pp. 75-83.

21. Yawney, C.D.; Homiak, J.P. Rastafari. In Encyclopaedia of African and African-American Religions; Glazier, S.D., Ed.; Routledge: New York, NY, USA, 2001; pp. 256-268.

22. Barrett, L.E. The Rastafarians; Beacon Press: Boston, MA, USA, 1997.

23. Wallace, A.F.C. Revitalization movements. Am. Anthropol. 1956, 58, 264-281. [CrossRef]

24. Erskine, N.L. From Garvey to Marley: Rastafarian Theology; University of Florida: Gainesville, FL, USA, 2004.

25. Calhoun, C. New social movements of the early nineteenth century. Soc. Sci. Hist. 1993, 17, 385-427.

26. Buechler, S.M. New social movement theories. Sociol. Q. 1995, 36, 441-464. [CrossRef]

27. D'anieri, P.; Ernst, C.; Kier, E. New social movements in historical perspective. Comp. Politics 1990, 22, 445-458. [CrossRef]

28. Johnston, H.; Laraña, E.; Gusfield, J.R. Identities, grievances, and new social movements. In New Social Movements: From Ideology to Identity; Laraña, E., Gusfield, J.R., Johnston, H., Eds.; Temple University: Philadelphia, PA, USA, 1994; pp. 3-35.

29. Pichardo, N.A. New social movements: A critical review. Annu. Rev. Sociol. 1997, 23, 411-430. [CrossRef]

30. Cohen, J. Strategy or identity? New theoretical paradigm and contemporary social movements. Soc. Res. $1985,52,663-716$.

31. Melucci, A. Nomads of the present. In Social Movements and Individual Needs in Contemporary Society; Keane, J., Mier, P., Eds.; Hutchinson Radius: London, UK, 1989.

32. Haley, A. Roots: The Saga of an American Family; Hachette: New York, NY, USA, 2016.

33. Nelson Young-Belizean International Artist. Available online: https://www.facebook.com/Carribean.Arts. Belize/ (accessed on 17 January 2020).

34. A Picture Is Worth a Thousand Words. Available online: https://ourmissiontobelize.blogspot.com/2019/05/apicture-is-worth-thousand-words.html (accessed on 17 January 2020).

35. Chavannes, B. Social Origins of Rastafari; Institute of Social and Economic Research; University of the West Indies: Kingston, Jamaica, 1974.

36. Mack, D.R.A. From Babylon to Rastafari: Origin and History of the Rastafarian Movement; Research Associates School Times Publications Frontline Distribution International: Chicago, IL, USA, 1999.

37. Smith, M.D.; Augier, R.; Nettleford, R. The Rastafari Movement in Kingston; Institute of Social and Economic Research; University of the West Indies: Kingston, Jamaica, 1978.

38. Campbell, H. Rasta and Resistance: From Marcus Garvey to Walter Rodney; Africa World Press: Trenton, NJ, USA, 1985.

39. Nettleford, R.M. Mirror, Mirror: Identity, Race and Protest in Jamaica; William Collins and Sangster: Kingston, Jamaica, 1970.

40. Barnett, L.E. The Rastafarians: At Study in Messianic Culture in Jamaica; Institute of Caribbean Studies; University of Puerto Rico: Rio Piedras, Puerto Rico, 1969.

41. Bilby, K.M.; Leib, E. Kumina, the Howellite church and the emergence of Rastafarian traditional music in Jamaica. J. Appl. Microbiol. 1986, 19, 22-28.

42. Adamu, M.A. The legend of queen Sheba, the Solomonic dynastic and Ethiopian history: An analysis. Afr. Res. Rev. 2009, 1, 469-482.

43. Hill, R.A. The Marcus Garvey and Universal Negro Improvement Association Papers, Volume VI, November 1937-August 1940; University of California Press: Berkeley, CA, USA, 1990.

44. Cronon, E.D. Black Moses: The Story of Marcus Garvey; University of Wisconsin Press: Madison, WI, USA, 1969. 
45. Ashdown, P. Marcus Garvey, the UNIA and the black cause in British Honduras, 1914-1949. J. Caribb. Hist. 1981, 15, 41-55.

46. Ashdown, P. Garveyism in Belize; Cubola Publications: Benque Viejo, Belize, 1990.

47. Shoman, A. Reflections on Ethnicity and Nation in Belize; 2010. Available online: http://citeseerx.ist.psu.edu/ viewdoc/download?doi=10.1.1.593.4800\&rep=rep1\&type=pdf (accessed on 14 December 2019).

48. Hill, R.A. Marcus Garvey and the UNIA Papers; UCLA Press: Los Angeles, CA, USA, 1983; Volume III.

49. Shoman, A. Thirteen Chapters of a History of Belize; Angelus Press: Belize City, Belize, 2000.

50. Medina, L.K. Defining difference, forging unity: The co-construction of race, ethnicity and nation in Belize. Ethn. Racial Stud. 1997, 20,757-780. [CrossRef]

51. Medina, L.K. Development policies and identity politics: Class and collectivity in Belize. Am. Ethnol. 1997, 24, 148-169. [CrossRef]

52. Medina, L.K. History, culture, and place-making: 'Native' status and Maya identity in Belize. In Perspectives on Las Américas; Gutmann, M.C., Matos-Rodriquez, F.V., Stephen, L., Zavella, P., Eds.; Blackwell Publishing Company: Malden, MA, USA, 2003; pp. 195-212.

53. Lyon, S.M.; Wells, E.C. (Eds.) Global Tourism: Cultural Heritage and Economic Encounters; Rowman Altamira: Lanham, MD, USA, 2012.

54. Barry, T.; Vernon, D. Inside Belize; Resource Center Press: Albuquerque, NM, USA, 1995.

55. Berl-Cawtran Consortium. Tourism Development 1984-1990 Strategy and Action Plan; Belize Archives Department: Belmopan, Belize, 1984.

56. Brown, D.F. Mayas and tourists in the Maya world. Hum. Organ. 1999, 58, 295-304. [CrossRef]

57. Sutherland, A. The Making of Belize: Globalization in the Margins; Bergin \& Garvey: Westport, CT, USA, 1998.

58. Van Wick, J. Romantic love. Etnofoor 2006, 19, 71-89.

59. Key, C.; Pillai, V.K. Tourism and ethnicity in Belize: A qualitative study. Int. Rev. Mod. Sociol. 2007, 33, 129-150.

60. Gallardo, A. Get up, stand up. Peace Rev. 2003, 15, 201-208. [CrossRef]

61. Toynbee, J. Bob Marley: Herald of a Postcolonial World; Polity Press: Cambridge, UK, 2007.

62. McCormack, E. Bob Marley with a bullet. Roll. Stone 1976, 10, 27-32.

63. White, T. Catch a Fire: The Life of Bob Marley; Henry Holt and Company: New York, NY, USA, 2006.

64. Alleyne, M. Globalisation and Commercialisation of Caribbean music. Pop. Music Hist. 2009, 6, 76-101.

65. Hagerman, B. Bob Marley: 1945-1981. In The Wiley Blackwell Encyclopedia of Race, Ethnicity and Nationalism; Stone, J., Dennis, R.M., Rizova, P.S., Smith, A.D., Hou, X., Eds.; John Wiley \& Sons: Hoboken, NJ, USA, 2015.

66. Yawney, C.D. Only visitors here: Representing Rastafari into the 21st century. In Religion, Diaspora and Cultural Identity: A Reader in the Anglophone Caribbean; Pulis, J.W., Ed.; Gordon and Breach Publishers: Amsterdam, The Netherlands, 1999; pp. 153-181.

67. Pruitt, D.; LaFont, S. For love and money: Romance tourism in Jamaica. Ann. Tour. Res. 1995, 22, $422-440$. [CrossRef]

68. King, S. Reggae, Rastafari and the Rhetoric of Social Control; University Press of Mississippi: Jackson, MS, USA, 2002.

69. Price, C. Becoming Rasta: Origins of Rastafari Identity in Jamaica; New York University Press: New York, NY, USA, 2009.

70. Gray, O. Demeaned but Empowered: The social power of the urban poor in Jamaica; University of West Indies Press: Kingston, Jamaica, 2004.

71. Belliveau, J. Romance on the Road: Travelling women who love foreign men; Beau Monde Press: Baltimore, MD, USA, 2006.

72. Oppermann, M. Sex tourism. Ann. Tour. Res. 1999, 26, 251-266. [CrossRef]

73. Clift, S.; Carter, S. (Eds.) Tourism and Sex: Culture, Commerce and Coercion; Cengage Learning EMEA: Boston, MA, USA, 2000.

74. Murphy, J. Rastaman Jungle Session. Available online: https://www.youtube.com/watch?v=PnOQ5O5zc0I (accessed on 20 January 2020). 
75. Canclini, N.G. Hybrid Cultures: Strategies for Entering and Leaving Modernity; University of Minnesota Press: Minneapolis, MN, USA, 1995.

76. Robertson, R. Glocalization: Time-space and homogeneity-heterogeneity. Glob. Mod. 1995. [CrossRef]

(C) 2020 by the author. Licensee MDPI, Basel, Switzerland. This article is an open access article distributed under the terms and conditions of the Creative Commons Attribution (CC BY) license (http://creativecommons.org/licenses/by/4.0/). 